Persp. Teol. 41 (2009) 191-210

\title{
GLOBALIZAÇÃO E MIGRAÇÃO: IMPLICAÇÕES ÉTICO-TEOLÓGICAS
}

(Globalization and migration: Ethical and theological implications)

Élio Estanislau Gasda SJ *

RESUMO: Estamos diante de um fenômeno estrutural da sociedade contemporânea, intenso, denso, complexo. As migrações são uma das faces mais impactantes do atual processo de globalização. Refletir sobre o drama destes pobres universais despojados de suas terras e de seu trabalho, afastados de suas famílias, extraídos de sua cultura, nos obriga a reconsiderar os atuais modelos de sociedade, os valores morais e certos conceitos determinantes da modernidade, como o de cidadania. Realidades e conceitos que afetam profundamente a consciência, a reflexão e a práxis humano-cristã.

PALAVRAS-CHAVE: Globalização, Migração, Cidadania, Direitos humanos, Moral social.

ABSTRACT: We are faced with a structural phenomenon of contemporary society; intense, dense, complex. The migrations are one of the most shocking aspects of the actual globalization process. To reflect upon the drama of these universal poor deprived of their land and of their work, separated from their families, extracted from their culture, forces us to reconsider the actual models of society, the moral values and certain determining concepts of modern time, such as citizenship. These are realities and concepts that profoundly affect the conscience, the reflection and the human-christian praxis.

KEY-WORDS: Globalization, Migration, Citizenship, Human rights, Social morality.

\footnotetext{
* Departamento de Teologia da FAJE - Belo Horizonte. Artigo submetido a avaliação no dia 28/07/2008 e aprovado para publicação no dia 03/09/2008.
} 


\section{A quem serve a Globalização?}

\section{Capitalismo global e reprodução da pobreza}

Tosso tempo é marcado pelo fenômeno da globalização socioeconômica, 1 política e cultural. É a denominação para o estágio atual do capitalismo, trata-se de uma realidade pluriforme e complexa, se desenvolve em diversos níveis e evolui de forma imprevisível. Pode produzir efeitos benéficos e novas oportunidades para a humanidade, despertar novas esperanças, mas também suscitar inquietações, angústias e medos, pois suas benesses não estão ao alcance de todos. Para grande desilusão dos mais otimistas e bem-intencionados, a globalização de matriz capitalista não reduziu as desigualdades e a pobreza. "No início do novo milênio, a pobreza de milhões de homens e mulheres é a questão que, em absoluto, mais interpela a consciência humana e cristã"1 . A desigualdade de renda entre os dois extremos da pirâmide social teve forte aceleração em todo o mundo. Se não se modificam radicalmente as taxas de desenvolvimento e as porcentagens de distribuição da riqueza, em 2020 a diferença entre a quarta parte mais rica e a quarta parte mais pobre será da ordem de 300\% superior à diferença atual².

Existem indivíduos, grupos e nações que conseguiram controlar o processo, enriquecer-se e gozar de níveis de vida muito mais altos que antes, enquanto isso, milhares de pessoas são empurradas para a marginalidade. A riqueza mundial está fortemente concentrada nos EUA-Canadá, na Europa e nos países ricos da Ásia e do Pacífico. Os habitantes desses países detêm juntos quase $90 \%$ do total da riqueza do planeta, enquanto na Ásia meridional, na África e em boa parte da América Latina, quase 1 bilhão de pessoas vive em condições de pobreza absoluta e degradante. As 200 pessoas mais ricas do mundo dispõem de mais recursos que 2 bilhões de pessoas mais pobres, US\$ 1 trilhão. Nos últimos 10 anos o número de pessoas que vivem na pobreza aumentou em 100 milhões, enquanto a renda global cresceu em média 2,5/ano. Mais de 10 milhões de crianças morrem a cada ano por enfermidades derivadas da subnutrição e mais de 700 milhões de adultos se encontram gravemente subnutridos ${ }^{3}$. Mas a ajuda estrangeira aos países pobres, onde reside $80 \%$ da população mundial,

\footnotetext{
1 JOÃO PAULO II, Mensagem para a celebração do Dia Mundial da Paz, 2000. Em: http://www.vatican.va. Todas as mensagens pontifícias estão retiradas desta página.

${ }^{2}$ Para uma excelente análise conjuntural e um levantamento das perspectivas sociais da globalização, cf. A. GIDDENS, Em defesa da Sociologia: Ensaios, interpretações e tréplicas, São Paulo: INESP, 2001.

${ }^{3}$ PNUD, Informe sobre Desenvolvimento Humano, ONU, 2006. Os relatórios, elaborados pelo Programa das Nações Unidas para o Desenvolvimento, PNUD, estão disponíveis em http://undp.org/hdro.192
} 
sofreu reduções contínuas. Em 1970, a maioria dos países desenvolvidos concordava em ajudar com recursos equivalentes a 0,7\% do PIB. Até 1990, o montante enviado tinha chegado a 0,35\%, mas em 2000 já tinha caído para somente $0,2 \%$ do PIB. A ajuda também diminuiu em volume de dólares. Em termos reais, descontada a inflação, os US\$ 53 bilhões doados em 2000 eram quase 1/3 menor do que as doações do ano de 19904. Fiel à sua natureza, mais uma vez o capitalismo deu as costas aos pobres.

Em 2005, 39,8\%, ou 210 milhões de latino-americanos se encontravam em situação de pobreza, a indigência (extrema pobreza) atingia mais de 80 milhões de pessoas ${ }^{5}$ e o déficit de emprego formal afeta a 126 milhões de pessoas, $53 \%$ da população economicamente ativa ${ }^{6}$. O Brasil conseguiu reduzir a população em situação de miséria, mas não reduziu a distância entre os muito ricos e os pobres. Ao contrário, a política econômica dos dois últimos governos transferiu muito mais renda para os ricos por meio das despesas financeiras, do que para os pobres pela assistência social e previdência pública. Apenas 35\% da população brasileira economicamente ativa conta com algum tipo de proteção social. Os ricos estão mais ricos, e os pobres, abandonados à sua própria sorte, sobrevivem das migalhas ${ }^{7}$.

Mais seres humanos são empurrados para a margem, e se submetem à vulnerabilidade social, a um número cada vez maior de zonas regionais e territoriais convertidas em zonas de sombra da nova cidadania do capitalismo global. Existem regiões que ganham e regiões que perdem, regiões que estão adquirindo uma cidadania privada em nível mundial, e outras, grandes franjas da humanidade deixadas à margem e sem nenhuma esperança, porque já não são necessárias. Os “inúteis para o mundo que vivem nele, mas não lhe pertencem realmente. Ocupam uma posição de supernumerários, flutuam em uma espécie de terra de ninguém social" ${ }^{8}$.

\section{Migrar: o êxodo dos desmembrados e desnecessários}

As migrações são um dos fenômenos sociais mais impactantes da globalização. A partir da década de setenta o número de imigrantes no planeta foi multiplicado por dois. Se em 1965 eram 75 milhões, neste novo

\footnotetext{
${ }^{4}$ J.A. FRIEDEN, Capitalismo Global, Rio de Janeiro: Jorge Zahar, 2008, p. 480.

${ }^{5}$ CEPAL, Panorama Social da América Latina, 2006. Fonte: www.eclarc.org.

${ }^{6}$ OIT, Trabajo decente en las Américas 2006-2015. (http://www.oitamericas.org). O déficit de trabalho formal pode chegar a 158 milhões de pessoas em 2015.

${ }^{7}$ Segundo dados do Instituto de Pesquisa Econômica Aplicada - Ipea (17/05/2008), 10\% da população concentra $75,4 \%$ da riqueza do País. Em 2007, a renda das classes A/B que recebem acima de dez salários mínimos por mês ( $\mathrm{R} \$ 3,8$ mil) cresceu 7,3\% em relação a 2006 e supera os estratos inferiores da população. O resultado superou a taxa de crescimento da média da população em geral, que foi de $5 \%$ para o período, e das classes mais pobres $\mathrm{C}$ e $\mathrm{D} / \mathrm{E}$, que registraram acréscimos de $4 \%$ e $2 \%$.

${ }^{8}$ R. CASTEL, As metamorfoses da questão social: Uma crônica do salariado, Petrópolis: Vozes, 1998, p. 416.
} 
século mais de 200 milhões vivem fora do seu país de origem. Ou seja, uma de cada 35 pessoas no mundo é imigrante 9 . A intensificação do fluxo migratório dos anos noventa resultou na imigração de 20 milhões de latino-americanos. Destes, uns 15 milhões vivem nos Estados Unidos. São cifras que incluem trabalhadores temporais, imigrantes permanentes, refugiados, e também suas famílias ${ }^{10}$. A população imigrante legal nos Estados Unidos passou de 4,8\% da população total em 1970, e atualmente situa-se próximo dos 10\%. Na Alemanha, França, Itália e Reino Unido o crescimento foi semelhante. Também a Espanha vem-se caracterizando como um país receptor ${ }^{11}$. Não estamos diante de um acontecimento inédito. As migrações são uma constante ao longo da história humana, reações mais expressivas na luta contra situações adversas à vida. Se antes da primeira metade do século XX os fluxos migratórios obedeciam aos sentidos NorteSul e Europa-Estados Unidos ${ }^{12}$, nas migrações atuais o influxo é inverso, Sul-Norte, e em escala muito superior, como mostram os dados acima.

Não são poucas as questões que surgem diante da intensidade e da complexidade do fenômeno migratório: é "espontâneo" ou "induzido"? "Voluntário" ou "forçado"? O que pode levar uma pessoa a deixar sua terra, pai, mãe, irmãos, investir o pouco que lhe resta, caminhar dias sob o calor escaldante do norte da África e enfrentar o frio da madrugada, sofrer extorsão, aguardar semanas por uma vaga em uma balsa de madeira com combustível insuficiente, abarrotada de homens, mulheres e crianças, sem as mínimas condições de fazer frente à força das ondas e das tempestades numa longa e perigosa travessia pelo Atlântico para vir morrer no Puerto de los Cristianos, em Tenerife? Ou viajar entre os eixos traseiros de um caminhão durante uma noite inteira e, no flagrante, ser algemado, encarcerado e devolvido, de mãos vazias, a El Salvador? Claro que nem todos chegam assim. A maioria consegue entrar nos países ricos como turista ou estudante, e permanece além do prazo legal. O fato é que, para muitos imigrantes, ter sua entrada negada por falta de um pedaço de papel, não só é humilhante, ofensivo e desesperador, mas uma sentença de morte.

\footnotetext{
${ }^{9}$ ONU - Organização Internacional de Migrações, Situação da migração no mundo, 2000. A maior parte vive na Ásia (44 milhões), EUA e Canadá (41 milhões) e Europa Ocidental (33 milhões). 63\% dos imigrantes residem nos países ricos (120 milhões) e representa $9 \%$ da população.

${ }^{10}$ CEPAL, Panorama Social de América Latina, 2004. Fonte: www.eclar.org.

${ }^{11}$ Em 1996 o número de residentes estrangeiros alcançava a cifra de 500 mil; dez anos depois já serão mais de 2 milhões de imigrantes legalizados, em que mais de $75 \%$ procedentes dos países pobres, principalmente latino-americanos e do Leste Europeu. A manter-se esta tendência, em 2010 a população estrangeira na Espanha irá superar a cifra de sete milhões, ou seja, $17 \%$ da população. Fonte: MINISTÉRIO DE ASSUNTOS EXTERIORES, Anuário Estatístico de Imigração, Instituto Nacional de Estadística INE, 2007.

${ }_{12}$ A partir de 1900, a cada ano, quase 1 milhão e meio de europeus saíram da Europa em direção do continente americano: cf. E. HOBSBAWN, A era do capitalismo, t. 2, Madrid: Alianza, 1977, pp. 36-37.
} 
O capitalismo global converteu o direito de emigrar em um dever para milhares de seres humanos. As migrações aparecem como a última tentativa de escapar da violência e da morte. Tomando por base o referencial demográfico, tem-se que os deslocamentos migratórios fazem parte da natureza humana, mas forçados, nos dias de hoje, nesta lógica inversa de sua preponderância em relação ao ser humano.

Abandonar o país tornou-se a única forma de encontrar oportunidades de vida e trabalho. As pessoas não estão migrando livremente em busca de melhores condições, mas forçadas pelas consequências perversas do capitalismo global. Dos 250 milhões de pessoas que vivem nos países do norte da África mais de 15 milhões entraram na Europa em busca de trabalho e melhores condições de vida. $\mathrm{O}$ fenômeno da imigração apresenta uma encruzilhada histórica: Nos próximos trinta anos, a massa laboral do México, América Central e países do Caribe aumentará em mais de 52 milhões de pessoas e na África, 323 milhões de novos trabalhadores serão incorporados à massa laboral, uma população em idade de trabalhar superior à força laboral existente em toda Europa ${ }^{13}$. A intensificação da imigração está colocando à disposição dos empresários um novo exército de reserva para trabalhar em setores como os serviços e construção, geralmente em condições precárias e baixos salários devido à falta de uma proteção jurídica mais específica. Os imigrantes em situação irregular são particularmente vulneráveis devido aos temores de deportação. Os setores que empregam mão-de-obra imigrante são objeto de pouco ou nenhum controle que garanta a segurança no trabalho. Os imigrantes ocupam os postos sujos, perigosos e difíceis (dirty, dangerous and difficult jobs).

A acolhida de imigrantes nos países ricos responde a uma opção puramente instrumental: oferece a possibilidade de preencher vazios do mercado de trabalho sem inserção social. Sua presença é tolerada enquanto responde ao crescimento econômico do país receptor. O critério dos limites da suportabilidade não pode ser a simples defesa do bem-estar das sociedades receptoras em prejuízo das necessidades fundamentais dos que clamam por uma recepção minimamente hospitaleira que salve suas vidas. Neste sentido, Stephen Fumio Hamao observa que o aumento da migração clandestina e o tráfico de seres humanos não podem ser ignorados quando se aborda o tema da mobilidade humana ${ }^{14}$. "Quando é difícil atravessar

\footnotetext{
${ }^{13}$ POPULATION CRISIS COMMITTEE, Population Pressures Abroad and Inmigration Pressures at Home, Washington DC, 2006.

${ }^{14} \mathrm{O}$ tráfico de seres humanos supera o tráfico de armas em termos de lucratividade ao movimentar US $\$ 32$ bilhões por ano e explorar mais de 2,5 milhões de pessoas. As estimativas falaram até agora de um negócio de US $\$ 10$ bilhões a US $\$ 15$ bilhões anuais de lucro para o crime organizado. O mercado do tráfico de mulheres para a indústria do sexo está estimado, em escala mundial, entre US\$ 7 e 12 bilhões anuais de um total de mais de 55 bilhões do total movimentado por esta indústria. Fonte: OSCE (Organização para a Segurança e a Cooperação Europeia), 2006.
} 
uma fronteira legalmente, e existe uma necessidade premente de fazê-lo, tentam de fato a migração não autorizada. Quando as pessoas estão despojadas de seus direitos, como os migrantes em situação irregular, é fácil explorá-las e maltratá-las para obter benefícios econômicos às custas delas"15. O denominador comum é a pobreza absoluta e a fragilidade da vítima. A exploração da miséria humana levada ao extremo.

Do ponto de vista jurídico, um rápido olhar sobre a legislação desmascara as discriminações. No século XIX, muitos países não adotavam diferenças entre os direitos dos nacionais e os dos estrangeiros ${ }^{16}$. As primeiras restrições aos direitos dos estrangeiros surgiram a partir das guerras mundiais ocorridas no século XX e não pararam mais ${ }^{17}$. A normativa europeia de regresso de nacionais de terceiros países em situação irregular aprovada pelo Parlamento Europeu em junho de 2008, converteu as pessoas procedentes de outros países que não estão com os documentos atualizados, em cidadãos de segunda categoria: todo imigrante nesta situação, inclusive crianças, idosos, portadores de deficiência, grávidas, vítimas de perseguição, tortura, estupro ou outras formas de violência, será considerado um delinquente, ser preso e detido por até 18 meses em "campos de retenção", ou ainda, ser expulso do país, sem nenhuma garantia de reagrupamento familiar ${ }^{18}$.

\footnotetext{
${ }^{15}$ S. FUMIO HAMAO, Introdução ao Encontro Continental CELAM-SEPMOV, Bogotá, 2003. Fonte: www.vatican.va. O cardeal Stephen Fumio Hamao, falecido em 2007, foi presidente do Conselho Pontifício para a Pastoral dos Migrantes e Itinerantes.

${ }^{16}$ Legislações nacionais que equiparavam direitos: o Código Civil holandês (1839), o Código Civil chileno (1855), o Código Civil argentino (1869) e o Código Civil italiano (1865).

${ }_{17} \mathrm{O}$ Brasil não foge à regra. As Constituições de 34 e 37 refletem esta tendência. A Constituição de 1934, ápice do getulismo, veda a concentração de imigrantes em qualquer ponto do território nacional e impede que cada corrente imigratória exceda $2 \%$ do número

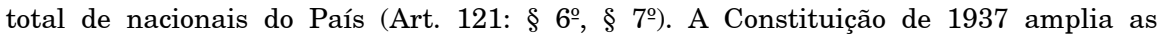
proibições migratórias, fixando como competência exclusiva da União legislar sobre migração, com poder de limitar certas raças ou origens. Com o fim da II Guerra Mundial, o Brasil entra em um período de expansão e flexibiliza a política de imigração para poder buscar mão-de-obra especializada, preferencialmente a europeia. Somente na Constituição de 1988 a legislação brasileira assegurará aos estrangeiros residentes no País a condição jurídica paritária à dos brasileiros no referente ao gozo de direitos civis: "Todos são iguais perante a lei, sem distinção de qualquer natureza, garantindo-se aos brasileiros e aos estrangeiros residentes no País a inviolabilidade do direito à vida, à liberdade, à igualdade, à segurança e à propriedade (Art. $5^{\circ}$ ). Porém, o atual Estatuto do Estrangeiro foi editado em plena ditadura militar, a Lei 6.815/80.

${ }^{18}$ Também chamada de Diretiva da Vergonha, eis as condições de detenção e retenção: em princípio, há espaços isolados denominados centros de retenção. Porém, em caso de superlotação, os estrangeiros podem ser mesclados aos presos comuns e as famílias, separadas. A expulsão está acompanhada de uma interdição de entrada em todo território coberto pela diretiva, que pode durar cinco anos ou indefinidamente. O Estado pode considerar desnecessária a tradução de tais documentos, desde que se possa supor que o expulsado os compreenda. Como se não bastasse, as informações sobre as causas da expulsão podem ser negadas, por razões de segurança nacional. Calcula-se que podem ser
} 
Este endurecimento da União Europeia em relação ao tema revela que ainda não existe uma legislação internacional sólida sobre as migrações internacionais. "O maior vazio da atual estrutura internacional da economia global é a ausência de um marco multilateral que regule o movimento transfronteiriço de pessoas. [...] ... enquanto que os direitos relativos ao investimento estrangeiro foram se reforçando cada vez mais nas regras estabelecidas para a economia global, deu-se muito pouca atenção aos direitos dos trabalhadores"19. Existe uma evidente contradição entre os obstáculos que impedem a livre mobilidade humana e a enorme facilidade com que os capitais e seus proprietários migram, sem aviso prévio, de uma nação a outra. Após a assinatura do Tratado de Livre Comércio entre Canadá, México e Estados Unidos, por exemplo, este último reforçou as medidas de controle de imigração. Enquanto as correntes de capital se movem por todo o globo atravessando fronteiras na velocidade da luz, a mobilidade dos trabalhadores está fortemente policiada e limitada por sua vinculação à família, ao direito, à cultura, à xenofobia.

\section{A cidadania em questão}

Idas e vindas em todas as direções. Muitos rostos, muitas rotas: refugiados, vítimas do tráfico de seres humanos e do turismo sexual, trabalhadores temporários, técnicos, jovens, mulheres, ciganos, soldados, deportados, expulsados etc. Multidões acampadas, em alerta, à espera do menor sinal de trabalho. Mais muros são levantados, cercas são eletrificadas, leis hostis e xenófobas são aprovadas, invertem-se escalas de valores, direitos humanos são violados... em nome da cidadania. O fenômeno da imigração nos obriga a repensar muitos conceitos tradicionais considerados "intocáveis". Um dos mais importantes é o de cidadania. Afrontar a situação das migrações nos leva a perguntar pelos modelos de cidadania em vigor, a fim de pensar novas formas de organizar as relações sociopolíticas entre os membros da comunidade humana. Simplesmente não existe um marco político global que institucionalize uma determinada cidadania universal ou cidadania cosmopolita além do marco das comunidades nacionais concretas.

expulsos mais de 8 milhões de estrangeiros considerados em situação irregular, mesmo que sejam trabalhadores e não tenham praticado nenhum ato criminoso. É a concretização jurídica do projeto Europa fortaleza, liderado por Silvio Berlusconi e outros políticos conservadores. Poucas semanas após a aprovação desta diretiva, o Senado italiano converteu em lei um decreto do primeiro ministro que prevê prisão de até quatro anos para imigrantes sem visto de residência, prisão de seis meses a três anos para proprietários italianos de imóveis alugados a imigrantes ilegais. O texto também aumenta em um terço a pena de prisão para estrangeiros ilegais julgados por outros crimes.

${ }^{19}$ ONU - Comissão Mundial sobre a Dimensão Social da Globalização, Informe "Por uma globalização justa: criar oportunidades para todos", 2004. 
Sua concepção moderna vem dando mostras de insuficiência e necessita uma revisão.

\section{Um conceito em evolução}

O termo cidadão faz referência à identidade política dos indivíduos, sua identidade no espaço público. O conceito de cidadania é a fórmula criada para definir a forma de inserção dos indivíduos na sociedade política; uma relação política entre um indivíduo e uma comunidade, em virtude da qual o indivíduo é membro de pleno direito desta comunidade, ou não. A história ocidental ensina que os modelos de cidadania são contingentes, surgem como consequência de condições sociais, transformações geopolíticas e culturais que reduzem ou ampliam o grupo de cidadãos que compõem a comunidade política.

$\mathrm{Na}$ Atenas do século $\mathrm{V}$ a. C., os cidadãos da cidade-estado eram os protagonistas da vida social e política. Nem todos os habitantes eram considerados cidadãos da pólis e membros da demos. O título de cidadão era privilégio de uma minoria que tinha uma posição de superioridade que lhe garantia o direito de participação no governo da cidade. Ser homem em plenitude é ser zoon politikon, ou seja, participar na deliberação dos assuntos públicos da pólis, direito exclusivo de homens livres e iguais. Igualdade entendida como direito da palavra na assembleia (isegoría) e igualdade diante da lei (isenomía), como ensinou Aristóteles. Os cidadãos tinham direito de possuir terras, casas, remuneração pelo exercício político, proteção social na velhice, ingressos para o teatro, etc. Mulheres, crianças, escravos, estrangeiros não eram considerados cidadãos. A cidadania era um privilégio reservado ao varão ateniense de nascimento. $\mathrm{O}$ trabalho doméstico e o modelo econômico assentado no regime escravista asseguravam todas as condições para sua participação nos assuntos políticos. Os estrangeiros eram habitantes de segunda: obrigados a pagar impostos, não podiam ser proprietários, nem utilizar a terra para a pecuária, era-lhes proibido participar da assembleia, e sem direito a liberdade religiosa.

Durante o Império Romano, com sua extensão geográfica, multiplicidade cultural e religiosa, o conceito de cidadania será ampliado. $\mathrm{O}$ desenvolvimento do Direito possibilita a descoberta da sua dimensão jurídica. A cidadania entendida como estatuto legal será capaz de acolher tanto a indivíduos de distintas origens raciais como a membros de diversas classes sociais. O cidadão romano (civis) é membro de uma comunidade política subordinada à mesma lei, vive sob o manto da lei e é protegido por ela em qualquer parte do Império ${ }^{20}$.

\footnotetext{
${ }^{20}$ Da Judeia, Paulo de Tarso pôde apelar ao seu estatuto jurídico de cidadão romano ante as ameaças da pena capital (At 22,25-29).
} 
A sociedade política moderna ocidental está conformada pela tríade Estado-nação-cidadania, que define os marcos das ações políticas, da legalidade e quem está dentro ou fora da demos (comunidade política). O sentido moderno de cidadania está ligado à ideia de Estado-nação. É a cidadania da afirmação dos direitos individuais frente à comunidade política, em que o Estado e a lei devem lealdade e proteção aos interesses individuais ${ }^{21}$. A cidadania equivale a direitos civis invioláveis. A sociedade política moderna se caracteriza pela consolidação do Estado como estrutura administrativa percebida como uma entidade diferenciada da sociedade, mas destinado a governá-la: governante e governado, em que o segundo elege o primeiro para representar e fazer valer seus interesses (Contrato Social, de Rousseau). Neste modelo de democracia há uma longa caminhada até que se reconheça a todos - independentemente de gênero, renda, instrução ou profissão - o direito de representação. Neste sentido, o princípio de cidadania moderno se caracteriza pela relação entre o cidadão e Estadonação. Cabe ao Estado, como formação política que exerce as funções legais, administrativas e penais, definir quem é cidadão e membro da nação dentro de seus limites territoriais. Nação entendida como entidade simbólica que vincula território administrado pelo Estado e cidadania, garantindo a coesão, a unidade e a estabilidade da comunidade. Desta forma, o Estado-nação é a única mediação, o único elo que o indivíduo possui para existir como alguém na comunidade humana, na sociedade internacional. O Estado é um dos pilares das sociedades modernas. Tanto se os governos fossem liberais, como conservadores, social-democratas, fascistas ou socialistas, no momento de seu apogeu os parâmetros de vida dos cidadãos estavam determinados pelo Estado.

\section{$A$ insuficiência do Estado-nação para conferir cidadania}

Esta ideia de cidadania nacional-estatal concebida na modernidade está em processo de mudança e necessita ser reelaborada. O sistema de Estados soberanos está em crise. Este sistema se afirmou na Europa com a paz de Westfalia, que pôs fim à Guerra dos Trinta anos e se consolidou como um modelo de ordenamento internacional moderno: pluralismo dos Estados nacionais, territoriais e soberanos. Esta soberania era ad intra, como uma potestade exclusiva de autoridade por parte do Estado a respeito dos seus cidadãos. E ad extra como independência a respeito da ordem internacional. Do ponto de vista jurídico, o sujeito do direito internacional são os Estados. Não se reconhece nenhuma subjetividade jurídica internacional a entidades coletivas. A fonte exclusiva do direito internacional é a autoridade soberana dos Estados. Este modelo ocidental se estende por quase todo

\footnotetext{
${ }^{21}$ J. LOCKE (1632-1704), pai do liberalismo político, escrevia que o Estado tem uma origem contratual e sua única finalidade é proteger direitos individuais a fim de conseguir o bem público (Segundo tratado sobre o governo civil, cap. 1, 3).
} 
o planeta no início do século XX e permanece inalterado até a II Guerra Mundial, sofrendo algumas poucas revisões com a criação da ONU.

O processo de reconfiguração do capitalismo traz mudanças no papel dos Estados. É verdade que controlam seu território, mas estão perdendo o controle regulador sobre setores-chave do sistema econômico, como o fluxo de capitais, as transnacionais, os preços, o valor da moeda, a informação. A soberania dos Estados está sendo sufocada pelo poder de sujeitos supranacionais. Em contexto de uma realidade mundial altamente interconectada, muitos dos domínios tradicionais de atividade e responsabilidade estatal não podem ser regidos sem recorrer a formas internacionais de cooperação. $\mathrm{O}$ avanço da integração econômica e política internacional é um fato. Do ponto de vista político, a globalização significa que a humanidade está deixando para trás a época da política internacional caracterizada pelo monopólio dos Estados Nacionais no cenário mundial. Entramos em uma era de política pós-internacional em que os atores nacionais-estatais devem dividir o cenário e o poder com organizações internacionais (OTAN, OMC, MERCOSUL, UE, BM, FMI), cúpulas e fóruns, empresas e movimentos sociais internacionais (Greenpeace, Anistia Internacional, Médicos Sem Fronteiras, Oxfam). Estamos diante de uma irreversível policêntrica política mundial: organizações transnacionais, problemas transnacionais (imigração, câmbio climático, narcotráfico, fome, SIDA, crise econômica, energia), eventos transnacionais (esporte, guerra, arte, eleições, cúpulas), estruturas transnacionais (Bolsa de valores, divisão do trabalho, conhecimento-informação). Com a globalização, a política nacional-estatal perde o núcleo de seu poder: a soberania ${ }^{22}$. Sufocado pela economia global, o Estado-nação está perdendo a capacidade de organizar a convivência humana e sustentar a vida do indivíduo, convertido em consumidor pelo mercado. A cidadania afincada no estado-nacional se vê desbordada pelas novas dimensões espaçotemporais da globalização.

Se a cidadania está inscrita no marco do Estado-nação, os direitos correspondentes ao cidadão são atribuídos apenas enquanto membros de uma nação, de um povo. Ou seja, são direitos originados de uma condição particular e exclusivos dos membros desta nação. O fenômeno da globalização questiona este caráter privatista e limitado da ideia de cidadania. Portanto, já é hora de redefinir as pautas de organização das relações sociais entre os seres humanos, em chave mais universalista. Neste sentido, a globalização capitalista representa, entre outras coisas, um progressivo esvaziamento do conteúdo do conceito cidadania e das instituições jurídico-políticas.

${ }^{22}$ Cf. D. HELD, Prós e contras da Globalização, Rio de Janeiro: Jorge Zahar, 2001. Um dos maiores estudiosos do assunto, o autor analisa as principais contribuições ao debate dos problemas de natureza política surgidos durante o processo de globalização: a crise dos Estados, a supremacia do poder econômico, as enormes desigualdades sociais, os impasses no interior dos direitos políticos do cidadão, as hipóteses e possibilidades da democracia global, e também as perspectivas de futuro para a política. 
A atual crise de territorialidade e autoridade dos Estados Nacionais diante da economia capitalista global obriga a reformular a pergunta pela cidadania de indivíduos concretos. Ora, os direitos do cidadão, de caráter geopolítico, estão fundados nos direitos humanos, de caráter universal. É inquestionável a prioridade dos direitos humanos sobre os direitos do cidadão. A cidadania de alguns não pode estar acima dos direitos humanos de todos. As discriminações entre cidadão nacional e estrangeiro não se justificam mais, tanto na não atribuição de determinados direitos como no relativo ao não reconhecimento do estrangeiro como membro da comunidade política.

\section{Olhar da fé: Migração, sinal dos tempos}

Para Bento XVI, as migrações são um "sinal dos tempos" ${ }^{23}$. Segundo a Instrução Erga Migrantes Caritas Christi ${ }^{24}$, "as migrações internacionais são vistas e consideradas, com razão, como um importante componente estrutural da realidade social, econômica e política do mundo contemporâneo". O fato de que milhões de seres humanos sejam forçados a sair de sua terra para sobreviver é um dos sinais mais claros de que o mundo está em crise. Do ponto de vista econômico-social, as migrações constituem um espelho das mazelas do capitalismo global: Sobre a lógica do progresso econômico e do desenvolvimento social impera a lógica do lucro, onde todos os bens, objetos e valores são passíveis de negociação, como as pessoas e até os seus órgãos, a educação, a sexualidade e, inevitavelmente, os migrantes. A globalização neoliberal dissolve as estruturas produtivas tradicionais dos países pobres, degrada o ambiente, provoca a desertificação, além das secas, inundações e os conflitos armados internos. Estes fatores desestabilizadores das economias e das sociedades locais obrigam as pessoas a abandonar seus países porque foram destruídas suas formas habituais de sobrevivência.

\section{Sistema injusto estruturado no pecado}

O drama da migração no início do século XXI é uma das muitas formas de violência contra os desprotegidos causada pelo capitalismo global, tantas vezes denunciado pelo Magistério Social da Igreja. Diante da mundialização dos conflitos sociais, do aprofundamento do abismo entre ricos e pobres, da marginalização de povos inteiros, e das diferenças sociais cada vez mais escandalosas (PP, 3, 8, 9, 57 ${ }^{25}$, o fundador da Comissão de Justiça e Paz,

\footnotetext{
${ }^{23}$ BENTO XVI, Mensagem para a Jornada Mundial das Migrações, 2006.

${ }^{24}$ CONSELHO PONTIFÍCIO DA PASTORAL PARA OS MIGRANTES E ITINERANTES,

A Caridade de Cristo para com os migrantes, Santa Sé, 2004.

${ }_{25}$ As encíclicas e documentos pontifícios serão identificados pelas siglas tradicionais: Catecismo da Igreja Católica (CIC), Centesimus annus (CA), Compêndio da Doutrina
} 
Paulo VI (1963-1978), proclamava na Populorum Progressio (1967) que “já é momento de agir" (PP, 80). O realismo histórico do pontífice Montini o torna um dos primeiros reivindicadores da justiça social em escala planetária. Paulo VI defendia que as relações entre o Norte opulento e o Sul empobrecido ocorressem dentro do marco de "diálogo de civilizações" $(\mathrm{PP}, 73)$ a fim de reduzir os abismos, pois "está em jogo a vida dos pobres e a paz no interior dos países em vias de desenvolvimento e de todo o mundo" (PP, 55). "Paz ... que comporta uma justiça mais plena entre os homens". Para os países pobres e em meio a um mundo injusto "o desenvolvimento que busca a igualdade é o novo nome da paz" (PP, 76).

No Sínodo dos Bispos de 1971, A Justiça no mundo, convocado por Paulo VI, a Igreja volta a chamar a atenção para as contradições implícitas nas novas possibilidades oferecidas à humanidade pelo desenvolvimento tecnológico e sua coexistência com o aumento das desigualdades sociais entre países ricos e países pobres, vítimas da perversidade reinante que "produz massas de marginalizados, subalimentados que vivem em habitações desumanas, analfabetos, privados de poder político". Não há como resolver tamanha contradição sem superar os "sistemas e mecanismos injustos e internacionais de dominação". Caso contrário, boa parte da humanidade estará sendo submetida a uma nova forma de colonialismo, em que as nações neocolonizadas serão vítimas do jogo das forças econômicas internacionais colonizadoras.

O pontificado de João Paulo II (1978-2005) coincidiu com a aceleração do processo de globalização. A partir de uma alusão em seu Discurso à Assembleia da ONU (05/12/1995) a referência nominal ao fenômeno da globalização passa a integrar todas as suas Mensagens para a Jornada Mundial da Paz, das Migrações e demais discursos e alocuções de caráter social. Como não poderia ser diferente, a preocupação pelos marginalizados e desfavorecidos, pelas minorias indefesas e pela humanidade abandonada em seu sofrimento foi um dos grandes marcos de seu pontificado.

Do ponto de vista socioeconômico e político, o mundo contemporâneo vive sob o domínio da injustiça. Vale lembrar que seu pontificado transcorre entre os anos imediatamente anteriores e posteriores ao colapso do capitalismo totalitário de Estado do Leste Europeu controlado por Moscou (CA, 35). Porém, o surgimento de uma nova configuração da geopolítica mundial não modificou o quadro das injustiças sociais, o abismo Norte-Sul continua, o gasto em armamento foi multiplicado ao mesmo tempo em que milhões de pessoas morrem de fome. A leitura teológica da realidade global oferecida por João Paulo II na SRS é categórica: O sistema mundial está

Social da Igreja (CDSI), Gaudium et spes (GS), Laborem exercens (LE), Mater et magistra (MM), Octogesima adveniens (OA), Pacem in terris (PT), Populorum Progressio (PP), Rerum novarum (RN), Sollicitudo rei socialis (SRS). 
alicerçado em "estruturas de pecado" ${ }^{26}$. As causas das desigualdades sociais e do aumento da pobreza devem ser buscadas nos "mecanismos econômicos, financeiros e sociais" (SRS, 16). As estruturas de pecado e seus mecanismos perversos são fruto de decisões pessoais, excluindo qualquer justificativa fatalista ou de isenção de responsabilidade para com elas (SRS, 36).

O diagnóstico da $S R S$, com algumas matizações, não perdeu sua atualidade, e suas exortações à mudança das estruturas continuam válidas. Em sua última encíclica social, a Centesimus annus, João Paulo II constata que as estruturas de pecado foram reforçadas, agravando ainda mais a dramática situação dos mais pobres (CA, 35, 56). A encíclica de 1991 denuncia não somente a exploração dos pobres no chamado Terceiro Mundo, mas também as bolsas de pobreza e exclusão no interior das sociedades capitalistas avançadas. Não é objetivo do capitalismo satisfazer as necessidades humanas mais elementares e resolver o problema da pobreza (CA, 40). Já nas origens do capitalismo industrial e da sociedade de mercado, a Igreja, por meio da encíclica Rerum novarum, denunciava a miserável condição de extrema pobreza a que o novo e violento processo de industrialização havia reduzido grandes multidões de trabalhadores e suas famílias. Também hoje, em muitas partes do mundo, semelhante processo de transformação econômica, social e política vem causando os mesmos males (CA, 11). O capitalismo, estruturado no pecado, é a rejeição do humano, tanto pessoal como estruturalmente pensado. O pecado do mundo, encarnado em tais estruturas, rompe com toda a verdade do humano e desmascara o próprio sistema como uma grande farsa travestida de pretensa moralidade, pois leva o homem a enganar-se a si mesmo.

\section{Migrante: uma presença que interpela}

Para o pontífice polonês, o fenômeno migratório era um problema ético que deveria conduzir a sociedade na busca de outra organização mundial mais justa, que distribua os bens da terra de maneira racional e equitativa ${ }^{27}$. A citada Instrução da Santa Sé afirma que "o fenômeno migratório suscita uma autêntica questão ética, a busca de uma nova ordem econômica internacional para uma mais justa distribuição dos bens da terra. [...] na visão

\footnotetext{
${ }^{26}$ A aceitação desta categoria percorreu um longo caminho. O documento sobre a paz, da II Conferência do episcopado latino-americano de Medellín (1968), afirma que "ao falar de uma situação de injustiça nos referimos às realidades que expressam uma situação de pecado" (Paz, 1). Também os bispos reunidos em Puebla (1979) consideram como situação de pecado o enorme abismo entre ricos e pobres (28) originada por estruturas sociais, políticas e econômicas injustas (1155) "que obstaculizam a passagem de situações menos humanas a mais humanas" (16). O Documento de Puebla qualifica como estruturas de pecado os fatores causadores de miséria, um autêntico escândalo para a fé cristã e que, por isso, devem ser superadas (28). Por fim, também a VI Assembleia do Sínodo dos Bispos sobre Reconciliação e Penitência (1985) dá espaço ao tema do pecado social e do pecado estrutural, sendo recolhido na $S R S, 36$.

${ }_{27}$ JOÃO PAULO II, Mensagem para a Jornada Mundial das Migrações, 1999.
} 
da comunidade internacional como família de povos". Apela, pois, por um novo e incisivo empenho na educação e na pastoral, na ótica "de uma formação à 'mundialidade', isto é, a uma nova visão da comunidade mundial, considerada como família de povos, à qual finalmente são destinados os bens da terra, numa perspectiva do bem comum universal" (n. 8). "Muitos homens e mulheres, em diversas partes do mundo, sentem como próprias as injustiças e as violações dos direitos humanos [...]. Esta tomada de consciência é sinal de que as mazelas da realidade social adquirem estatuto moral" (SRS, 38). Esta "indignação ética" desperta a esperança na possibilidade de superação das estruturas de pecado e seus mecanismos perversos de exclusão social.

\section{$A$ instrução bíblica}

\section{(a) Aprender de Deus: amá-los como a ti mesmo (Lv 19,33-34)}

A Sagrada Escritura, fonte primeira da moral social, nos instrui que, já no Antigo Testamento, Deus se revela como um Deus acolhedor. Deus acolhe, de maneira preferencial, aqueles que a sociedade tem tendência a desprezar. A atenção de Yavé para com os órfãos, viúvas e estrangeiros é um fio que perpassa toda a Sagrada Escritura. Em relação ao estrangeiro, afirma, de forma categórica, o princípio de que, antes de ser membro de um determinado país, todo ser humano é membro da comunidade humana universal (Gn 1,26-30; 9,6b-7), que tem direito de viver com dignidade dentro de seu próprio país e, quando isso não é possível, tem todo o direito de buscar sua sobrevivência em outro território (Gn 12,1; Gn 47,4-6). A dignidade da pessoa é o grande valor a ser respeitado.

Um olhar sobre a história do povo de Israel bíblico ajuda a descobrir que o dever da hospitalidade ao estrangeiro estava profundamente arraigado em muitas culturas do mundo antigo. $\mathrm{O}$ autor da Carta aos Hebreus, em referência aos três forasteiros hospedados por Abraão em Mambré (Gn 18,2), exorta à "hospitalidade, pois, graças a ela, alguns, sem saber, acolheram anjos" ( $\mathrm{Hb} 13,2)$. O povo de Israel sentiu em sua própria carne o que era trabalhar e viver em um país estranho (Gn 12,1-10; 26,1-6). O primeiro credo de Israel proclama esta experiência histórica "Meu pai foi um arameu errante..." (Dt 26,5). Abraão, o pai da fé, foi um imigrante perpétuo, "um simples forasteiro que vive entre vós" (Gn 23,4). Também os hebreus emigraram por uma razão semelhante à dos dias de hoje, a fome (Gn 26,1; 41,54-57; 42-43). A dramática experiência de imigração produziu uma das primeiras legislações em defesa do imigrante, o Código da Aliança: "não oprimirás nem humilharás o imigrante, porque vós fostes imigrante no Egito" (Ex 22,20, cf. 23,9). Os imigrantes são citados junto ao órfão e à viúva: membros mais indefesos da comunidade (S1 94,6; 146,9; Jr 7,6; Ez $22,70)$. Objetos do amor preferencial de Deus, "que faz justiça ao órfão e à viúva, e que ama o imigrante, dando-lhe pão e manto" (Dt 10,18). 
O direito do imigrante não pode ser violado: "não violarás o direito do imigrante, nem do órfão ou da viúva (Dt 24,14-18). A Lei de Moisés assegura mesmos direitos a imigrantes e nativos: "Quando um migrante vier morar junto a ti, na vossa terra, não o explorareis; esse migrante que mora entre vós, tratá-lo-eis como um nativo, como um de vós; amá-lo-ás como a ti mesmo" (Lv 19,33-34). Para a religião de Israel, diante de Deus somos todos imigrantes: "A terra é minha, não passais de migrantes e moradores na minha propriedade" ( $\mathrm{Lv}$ 25,23). Em relação aos direitos e deveres legais, o estrangeiro e o nativo serão julgados com equidade ( $\operatorname{Lv} 24,22)$.

\section{(b) Acolher a imagem viva de Deus: Eu era estrangeiro (Mt 25,35)}

Uma contemplação sobre três movimentos do mistério pascal apresenta logo de início o evento Cristo como um Deus encarnado e imigrante entre nós. O Evangelho nos mostra a encarnação do Verbo como um movimento migratório, em que o Filho de Deus arma sua tenda entre a humanidade (Jo 1,14). A seguir, o contemplamos como membro de uma família migrante, abandonando seu país para escapar da violência e da morte (Mt 2,13-23). Ato final, contemplar seu rosto no rosto de todo estrangeiro desprotegido clamando por hospitalidade (Mt 25,35). No próximo, um ser humano portador de direitos e da igualdade fundamental, está a imagem viva de Deus, e deve ser amado e acolhido como tal.

O fenômeno migratório evoca grandes verdades da catequese batismal: Os Batizados em Cristo são peregrinos e estrangeiros neste mundo $(\mathrm{Hb} 13,14$; $1 \mathrm{Pd} 2,11)$; em Cristo, ninguém mais é estrangeiro ou migrante, mas membro do povo de Deus, plenamente integrado na família de Deus (Ef 2,19); "Para os revestidos em Cristo, não há mais judeu nem grego" (G1 3,28); a nova humanidade inaugurada pelo mistério pascal de Cristo, onde já não há mais grego e judeu, bárbaro, cita..., mas Cristo: ele é tudo e está em todos" (Cl 3,11). Na Igreja de Cristo, sacramento da humanidade nova, ninguém é estrangeiro. No abraço da cruz se rompem todas as fronteiras, barreiras e divisões (Ef 2,16). "Acolhei-vos uns aos outros, como o Cristo vos acolheu, para a glória de Deus" (Rm 15,7).

\section{Antigas e novas referências éticas}

\section{$O$ direito de migrar e o dever moral de acolher}

Para a moral social, melhor seria se as pessoas não tivessem que emigrar para sobreviver e vivessem com justiça e dignidade em sua própria terra (RN, 33; MM, 125; PT, 102, 106; GS, 66). A Igreja reconhece a todo ser humano o direito de procurar outro país em busca de melhores condições de vida. Neste direito de migrar (PT, 25), que está fundamentado no des- 
tino universal dos bens deste mundo e na busca de melhores condições de vida (MM, 30, 33, 45; PT, 102, 106; GS, 65; AO, 17; LE, 23) está intrínseco o dever dos Estados de acolher ao imigrante e favorecer sua integração social dentro de uma legislação não discriminatória (PT, 106; CIC, 2241). A regulamentação dos fluxos migratórios deve seguir os critérios de equidade e equilíbrio exigidos pela dignidade humana (CDSI, 298). O dever de acolhida se torna obrigação moral quando a vida e a segurança de quem chega está em risco. O critério para estabelecer a quantidade de emigrantes que podem entrar no país não pode estar limitado à simples defesa do bem-estar dos nativos, mas, principalmente, deve considerar as necessidades de quem, em situação desesperadora, se vê forçado a pedir hospitalidade $^{28}$. E acolher com hospitalidade significa "evitar com sumo cuidado toda discriminação em matéria de remuneração ou condições de trabalho. Toda a sociedade, em particular os poderes públicos, devem considerar o imigrante como pessoa, não como simples instrumento de produção; devem ajudá-lo para que traga para junto de si seus familiares e procure uma habitação decente, e devem favorecer sua incorporação na vida social do país de acolhida" (GS, 66).

Para as nações receptoras vale o imperativo cristão da centralidade dos pobres e da solidariedade com as vítimas das estruturas de pecado e seus mecanismos perversos (SRS, 43). A altura moral dos países ricos será medida pelo socorro a estas multidões desprotegidas e sem absolutamente nada (CA, 28). Os imigrantes que chegam semimortos aos portos dos países ricos, os refugiados, as vítimas do tráfico de seres humanos, são os pobres universais por excelência. $\mathrm{O}$ apelo à acolhida solidária e cuidadosa com $\mathrm{o}$ migrante está presente em toda a catequese social da Igreja.

\section{Dignidade humana e cidadania mundial}

Acolher o irmão que chega é um dever moral, mas insuficiente. Tal acolhida deve ser entendida num sentido mais amplo do que apenas oferecer trabalho, comida e pão. O princípio da dignidade humana traz uma exigência maior e mais comprometedora para a esfera das relações sociopolíticas: assegurar o título de cidadão ao imigrante. No reconhecimento dos direitos humanos como categoria de valor universal está implícita a reivindicação de uma cidadania humana independente do reconhecimento jurídico-político conferido pelo território de nascimento. Para a moral social, o fato de possuir uma nacionalidade e estar fora do país de origem não é impedimento para a cidadania universal (PT, 25).

O ensinamento de João XXIII foi resgatado em todo seu sentido por João Paulo II, defensor entusiasta do projeto de uma civilização universal fun-

${ }_{28}^{28}$ JOÃO PAULO II, Mensagem para a Jornada Mundial das Migrações, 1992. 
dada na dignidade da pessoa humana (LE, 7; SRS, 29; CA, 29). Para ele, os direitos humanos são o eixo organizador da convivência humana e a condição fundamental para a paz no mundo (LE, 16). Um tipo de desenvolvimento civilizatório que não defenda e promova os direitos humanos [...], incluídos o direito das nações e dos povos, não é digno deste nome (SRS, 33). Os direitos humanos constituem uma espécie de Lei Moral Universal, tornam possível o diálogo entre as nações e constituem a base da convivência humana, posto que "existem realmente direitos humanos universais, enraizados na natureza da pessoa, nas quais se refletem as exigências objetivas e imprescindíveis de uma lei moral universal"29.

A cidadania humana universal é uma exigência ética nascida da proclamação universal dos Direitos Humanos que a política e o sistema jurídico devem concretizar. Os direitos humanos não dependem de limites territoriais. Delimitações fronteiriças são circunstanciais, foram determinadas por acontecimentos históricos. A dignidade humana, não. Os imigrantes são, antes de tudo, pessoas. Antes de ser brasileiro, nigeriano, chinês ou boliviano, engenheiro, informático, odontologista, vendedor ambulante, analfabeto ou professor, ele é pessoa humana. Basta que uma vida seja concebida para que seja titular de direitos, mereça respeito, atenção e proteção. "Todo ser humano pertence, por natureza, ao gênero humano. Esta participação natural na família humana outorga a cada pessoa uma espécie de cidadania mundial, concedendo-lhe, naturalmente, a titularidade de direitos e deveres. A condenação do racismo, a tutela das minorias, a assistência aos exilados e refugiados, a mobilização da solidariedade internacional em prol de todos os desprotegidos, não são mais que aplicações coerentes do princípio da cidadania mundial" ${ }^{\prime \prime 30}$.

\section{Cidadão mundial: uma questão de justiça social}

A cidadania é uma relação política entre um indivíduo e uma comunidade, em virtude da qual o indivíduo é membro de pleno direito desta comunidade. O termo cidadão evoca a identidade política do indivíduo e sua identidade no espaço público. A cidadania é o status conferido aos membros de pleno direito de uma comunidade. O exercício da cidadania é o espaço próprio da sociabilidade, da vida ética e do exercício da justiça social. No decorrer dos tempos, a moral social cristã foi explicitando as exigências da justiça de acordo com as circunstâncias de cada época. A atualização do conteúdo do "dar a cada um o que é seu" se traduz hoje nos direitos fundamentais. Tais direitos afetam profundamente o campo da justiça social. A justiça social exige o estabelecimento de níveis mínimos de

\footnotetext{
${ }^{29}$ JOÃO PAULO II, Discurso na Assembleia Geral da ONU, Nova York, 05/12/1995.

30 JOÃO PAULO II, Mensagem para a Jornada Mundial da Paz, 2005.
} 
participação de todas as pessoas na vida da comunidade humana. Tal participação é a expressão da natureza social de todos os humanos. Negar tal forma de expressão da natureza humana a pessoas ou grupos representa uma grave violação da justiça social. Excluir o imigrante dos espaços de participação como se não fosse membro da humanidade e não reconhecêlo como interlocutor válido é violar sua dignidade humana. Toda situação de não reconhecimento do outro como irmão é uma perversão da identidade última do ser humano.

A constituição dos direitos humanos se situa no marco cosmopolita, posto que atribui a natureza de sujeito da ordem jurídica não somente aos Estados mas também aos indivíduos e aponta para a construção de uma "cidadania cosmopolita": uma cidadania e um sistema jurídico sem fronteiras, onde os direitos fundamentais das pessoas encontram proteção. Não estamos muito distantes de uma ética da comunidade universal civil da qual todas as pessoas participam. Isto não significa o desaparecimento do Estado-nação, mas sua adaptação ao processo de globalização. A propósito, os Estados têm um papel insubstituível na articulação desta cidadania cosmopolita, e de uma comunidade de nações como uma resposta firme a toda forma de imperialismo ${ }^{31}$.

O vínculo com todo ser humano é anterior a qualquer outro tipo de vínculo. Esse vínculo cosmopolita não é incompatível com o vínculo a uma determinada nação de origem sempre que este não se oponha às exigências éticas do primeiro. A identidade de cidadão do mundo não substitui à de cidadão de um país, apenas a precede. Os direitos humanos não têm pátria nem cor ou gênero. As constituições dos Estados não abarcam todo seu valor. Os refugiados e imigrantes são os que melhor concretizam esta realidade. A moral cristã defende a ideia de cidadania mundial porque a necessidade de garanti-la deve ser estendida a todos e a cada um dos seres humanos distribuídos por todo o planeta. Uma ética com pretensão de mundialidade deveria partir do princípio da dignidade humana e de suas consequências, pois o vínculo originário com toda a humanidade gera a obrigação moral de rechaçar certas práticas como a xenofobia, o genocídio, a limpeza étnica, a violência de gênero.

A nacionalidade, da qual tanto nos orgulhamos, não esgota toda a amplitude da dimensão do ser humano. Perder a nacionalidade não quer dizer perder a dignidade. Não se é menos humano quando se está em terra

\footnotetext{
${ }^{31}$ Além de D. HELD, a ideia de cidadania cosmopolita, ou seja, o reconhecimento de toda pessoa como cidadão do mundo, é defendida por autores como W. KYMLICKA, Ciudadanía multicultural: una teoría liberal de los derechos de las minorías, Barcelona: Paidós, 1996; A. CORTINA, Ciudadanos del mundo. Hacia una teoría de la ciudadanía, Madrid: Alianza, 2001; M.C. NUSSBAUM, Los límites del patriotismo. Identidad, pertenencia y "ciudadanía mundial", Barcelona: Paidós, 1999.
} 
estrangeira. A pertença à família humana, à sociedade universal confere a cada pessoa o estatuto de cidadania universal que não pode ser confinada a fronteiras nacionais decorrentes de uma visão parcial de pessoa humana. $\mathrm{Na}$ defesa dos direitos humanos dos imigrantes em qualquer parte do planeta está implícita a compreensão do conceito de cidadão numa visão de cidadania universal. Identificar uma pessoa como imigrante não justifica qualquer desrespeito aos direitos humanos, anteriores a qualquer norma legal ou fronteira geopolítica. Esta mudança do conceito de cidadania dependerá de uma nova consciência moral da humanidade. Se por um lado, a cidadania mundial não tem porque suprimir a categoria de cidadania vinculada ao Estado-nação, ela questiona que ela seja a única referência para garantir estatuto de cidadania aos indivíduos. Num mundo globalizado, o Estado-nacional não pode ser mais a única referência para tratar fenômenos de âmbito planetário como as migrações.

\section{Cidadãos do Reino}

Para a moral social cristã, “a imigração pode ser antes um recurso que um obstáculo para o desenvolvimento" (CDSI, 297), pois estamos ante um pluralismo cultural inédito na história. Esta era das migrações é uma das mais fortes expressões da aldeia global (McLuhan). Por outro lado, o drama do imigrante interpela a moralidade e obriga a romper com certas "verdades" intocáveis que foram impostas pela modernidade. Ora, a civilização não surgiu na modernidade. E a modernidade, muito menos, é a expressão mais acabada de civilização.

A mudança de perspectiva global no tratamento aos migrantes passa, necessariamente, pela mudança legislativa interna de países que consigam entender a problemática das migrações como uma realidade dramática na vida de milhões de seres humanos. A migração não é uma questão policial, é uma questão social em que está em jogo o respeito pela dignidade humana e os níveis de moralidade da sociedade contemporânea.

Implícito ao vaivém dos migrantes está o conceito de cidadania universal. O que dá direito à vida em qualquer lugar do planeta não é o passaporte, a carteira de trabalho, o RG ou o CPF, mas o fato de ser membro da comunidade humana. $\mathrm{O}$ fato de ter nascido, por si só, confere a todo ser humano uma cidadania inviolável. O migrante é portador privilegiado dessa bandeira, na medida em que se vê forçado a buscar proteção em terra estranha. Sua presença questiona o direito internacional e exige um alargamento de horizontes.

Urge enfatizar esse aspecto dos direitos humanos: o direito de ser cidadão do mundo. As condições em que vive a grande maioria da humanidade, 
entregue à pobreza, à miséria e à violência mostram que não mudaram as causas da exclusão. $\mathrm{O}$ ato de migrar é já uma forma de denúncia e de anúncio. Denúncia de uma ordem mundial marcada pela injustiça e a desigualdade, e anúncio de relações internacionais fundamentadas na justiça, na solidariedade e na paz.

O modelo de cidadania proposto pela moral social da Igreja pretende a superação do nacionalismo particularista e, sem pretender oferecer receitas nem respostas acabadas, nos ajuda a ampliar os horizontes do conceito de cidadania e contribui, também, com valiosos elementos éticos: o fundamento da dignidade humana, o bem comum em sentido universal, a solidariedade como princípio de ação. Valores que apontam para a necessidade de repensar o mundo não com base na competitividade econômica e o fechamento das fronteiras, mas, sim, na cidadania universal, na solidariedade e nas ações humanitárias.

Por fim, os imigrantes nos ajudam a desempoeirar verdades do existir humano e do estar neste mundo: nesta vida, somos todos estrangeiros, este mundo não é pátria definitiva para ninguém: "Então, virá gente do oriente e do ocidente, do norte e do sul, para tomar lugar na festa do Reino de Deus" (Lc 13,29).

Élio Estanislau Gasda SJ é mestre em teologia moral pela Pontifícia Universidade Comillas de Madrid (2005), doutorando pela mesma Universidade, e docente de Moral Social na Faculdade Jesuíta de Filosofia e Teologia (FAJE), em Belo Horizonte, MG.

Endereço: Rua Roberto Lúcio Aroeira, 318 - Itapoã 31710-570 Belo Horizonte - MG email: gasdasj@hotmail.com 